\title{
Discovering Factors of Foreign Language Speaking Anxiety and Coping Strategies
}

\author{
Vahid Rafieyan \\ International College of Liberal Arts, Yamanashi Gakuin University \\ Kofu, Yamanashi, Japan \\ E-mail: rafieyanv@ygu.ac.jp
}

Received: June 12, 2016 Accepted: June 27, 2016 Published: June 28, 2016

doi:10.5296/jsel.v4i1.9668 URL: http://dx.doi.org/10.5296/jsel.v4i1.9668

\begin{abstract}
Feeling of anxiety is commonly expressed by foreign language learners in learning to speak a foreign language. This feeling is considered to have a negative impact on communication in the target language. This study has attempted to investigate the most influential factors in creating this type of anxiety as well as the most commonly used strategies to cope with it. In this respect, a qualitative research methodology, based on interviews and reflective journals, was used to investigate the issue. A total of 10 female freshman undergraduate students of English education in Universiti Teknologi Malaysia participated in the study. The findings suggested that assessing language learners' speaking performance was the most anxiety provoking factor and creating a fun environment was the most commonly used strategy to cope with anxiety. The pedagogical implications of these findings suggested the significant role of teachers in creating and/or reducing foreign language speaking anxiety in language learners.
\end{abstract}

Keywords: Foreign Language Anxiety, Trait Anxiety, State Anxiety, Situation-Specific Anxiety, Intercultural Communication Apprehension 


\section{Introduction}

Fulfillment of the idea of creating a global village requires interaction with people of different nations. To achieve this goal, people of all ages attend English language classes as English has been recognized to be the international language. However, when it comes to speaking, anxious feelings inhibit these language learners from participating in classroom interactions.

Research over the relationship between anxiety and foreign language learning has been conducted since the mid-1960s. Early studies reported contradictory results. Some studies found that anxiety has a negative impact on foreign language learning. Some other studies found that anxiety has a positive impact on foreign language learning. However, there were also studies which concluded that anxiety does not influence foreign language learning. Scovel (1978) attributed this inconsistency in the results to utilizing different anxiety measures and suggested researchers to measure specific types of anxiety.

\subsection{Anxiety and Language Skills}

Although most researchers in the field of foreign language anxiety have considered the impacts of anxiety on speaking, some researchers have investigated the influence of anxiety on other language skills including listening, reading, and writing as well. Young (1990) and Phillips (1992) conducted two distinct studies over the influence of anxiety on language learners' oral performance. The results of both studies demonstrated that anxiety has a high negative impact on oral performance. Sellers (2000) investigated the influence of anxiety on American language learners' reading comprehension. He concluded that anxious language learners could not concentrate on their task which influenced their comprehension of the text. Elkhafaifi (2005) explored the relationship between general foreign language anxiety and language learners' achievement in an Arabic course. He also investigated the relationship between foreign language listening anxiety and language learners' listening comprehension. The results suggested a highly negative relationship between foreign language listening anxiety and some demographic variables in Arabic language courses. However, he found no significant relationship between gender and listening anxiety. Atay and Kurt (2006) conducted a study over 85 Turkish prospective English teachers to investigate the influence of foreign language writing anxiety on language teachers. More than half of these teachers experienced a high or an average level of writing anxiety.

\subsection{Factors of Anxiety}

Numerous scholars and language practitioners have investigated the factors which cause anxiety in foreign language classrooms. Krashen (1980) notes individuals with low self-esteem feel more anxious than those with high self-esteem. The reason is that they are worried about what their peers think. She also mentions that since teachers expect beginners to perform beyond their level of competence, speaking can result in high anxiety. Bailey (1983) reports language learners who compare themselves to other language learners or to the ideal self-image feel more anxious. Horwitz et al. (1986) and young (1990) believe that teachers' non-supportive correction results in language learners' anxiety. Price (1991) and 
Hembree (1988) state that language learners who feel they have a lower proficiency than the others may experience foreign language anxiety. Sparks and Ganschow (1991) argue that the disabilities of native language learning results in foreign language anxiety. Philips (1991) believes more speaking exercises to improve oral competence will increase anxiety and reduce motivation to learn a foreign language for language learners who experience foreign language anxiety. Yamoshiro and McLaughlin (2001) state high level of motivation results in high level of anxiety leading to a low level of proficiency.

\subsection{Strategies to Cope with Anxiety}

A number of strategies have been suggested to cope with anxiety. Kondo (1997) conducted a study to find out strategies that students use to cope with test anxiety. Four groups of coping strategies including cognitive, affective, behavioral, and resignation were reported. According to Hembree (1988) there are three approaches to cope with anxiety. The first one is cognitive approach which implies that the origin of anxiety is thinking disturbances that take place in the classroom. This approach suggests rational-emotive therapy and cognitive restructuring in order to avoid anxiety. The second approach is affective approach which tries to reduce the negative relationship between classroom and anxiety. In order to achieve this goal, this approach suggests biofeedback training, relaxation training, and systematic desensitization. Finally, behavioral approach implies that the origin of anxiety is poor academic skills. According to this approach, students can cope with anxiety by training in study skills.

\subsection{Types of Anxiety}

Anxiety has been categorized into various models by several scholars. Anxiety in educational setting is categorized into three groups: trait anxiety, state anxiety, and situation-specific anxiety. Trait anxiety is a stable personality trait that will cause the person feel anxious in various situations (Scovel, 1978). State anxiety is a temporary condition experienced at a certain time (Spielberger, 1983). Situation-specific anxiety is a trait occurring frequently in certain situations like tests or oral presentations (Ellis, 1994). Language learning anxiety falls into the category of situation-specific anxiety and is composed of communication apprehension, test anxiety, and fear of negative evaluation (Horwitz et al., 1986).

There are two models of anxiety: the interference retrieval model and the skills deficit model. The interference retrieval model refers to the problems at the output stage of learning. In this model, information learned in the past cannot be remembered. The skills deficit model refers to the problems at the input and processing stages of learning. Bad study habits or lack of information results in this model of anxiety (Tobias, 1985). In terms of effects on language learning anxiety, there are two types of anxiety: debilitating anxiety which poses an obstacle to language learning and facilitating anxiety which facilitates or fosters it (Scovel 1978 in Horwitz 1991; Young 1991; MacIntyre \& Gardner 1991a, 1991b).

Foreign language anxiety is composed of three components: communication apprehension, test anxiety, and fear of negative evaluation. Communication apprehension refers to the fear of communicating with others. Test anxiety refers to the fear of failure in test performance. Fear of negative evaluation looks like test anxiety but in a more general sense and refers to 


\section{Macrothink}

the anxiety resulting from different assessing conditions. (Horwitz et al., 1986).

\subsection{Anxiety from a Cognitive Perspective}

According to MacIntyre (1995) there is a recursive or cyclical relationship among anxiety, cognition, and behavior. For instance, requesting a student to answer a question might make him/her experience anxiety. This anxiety results in worry. As a result of the division of attention, cognitive performance reduces which reduces performance subsequently resulting in negative self-evaluation and more embarrassing cognition which will further reduce performance, and so on.

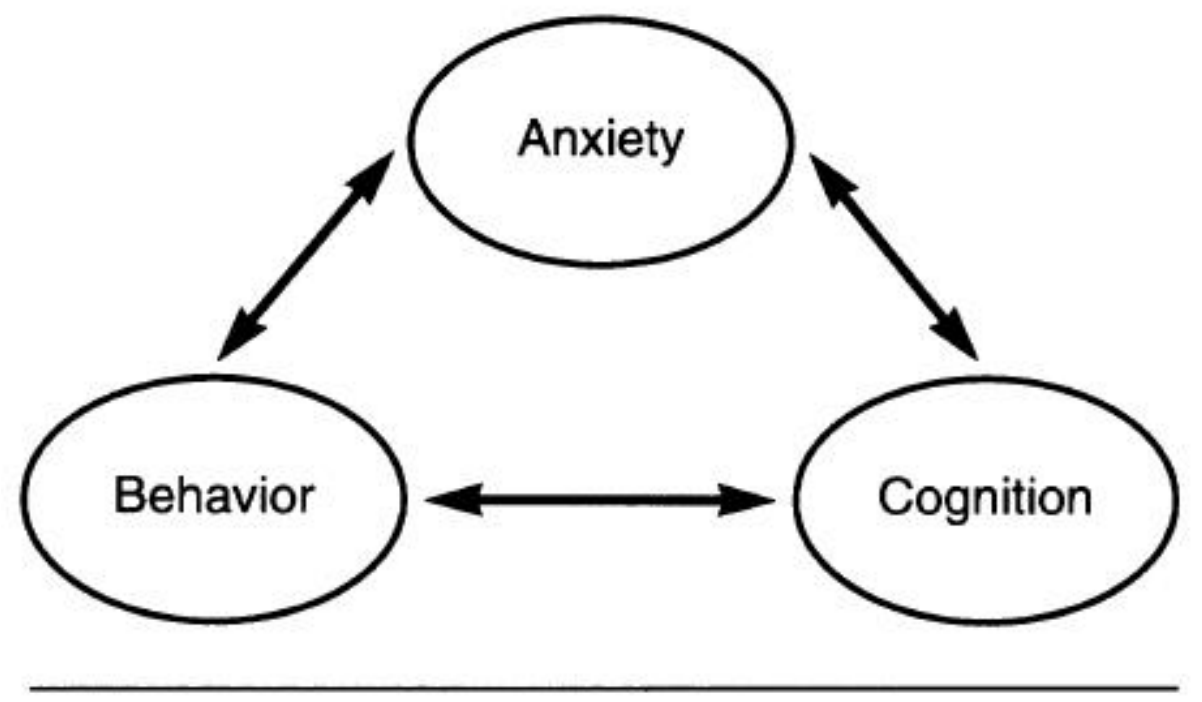

Figure 1. Recursive Relations among Anxiety, Cognition, and Behavior

Eysenck (1979) claims individuals who feel anxious try to make up for the raised cognitive demand by more effort. The degree to which anxiety improves or reduces performance depends on the level of effort by the anxious individual. Therefore, anxiety affects both performance quality and degree of effort. However, the level of effort is approximately fixed and the way quality of performance is influenced by anxiety should be put into consideration. This law provides a curvilinear relationship between anxiety and performance. When a task is easy, anxiety will enhance performance by raising effort. By an increase in the difficulty of a task, anxiety will decrease performance as more effort may not make up for the cognitive interference. A further increase in the difficulty of the task further increases the negative effects of anxiety. 


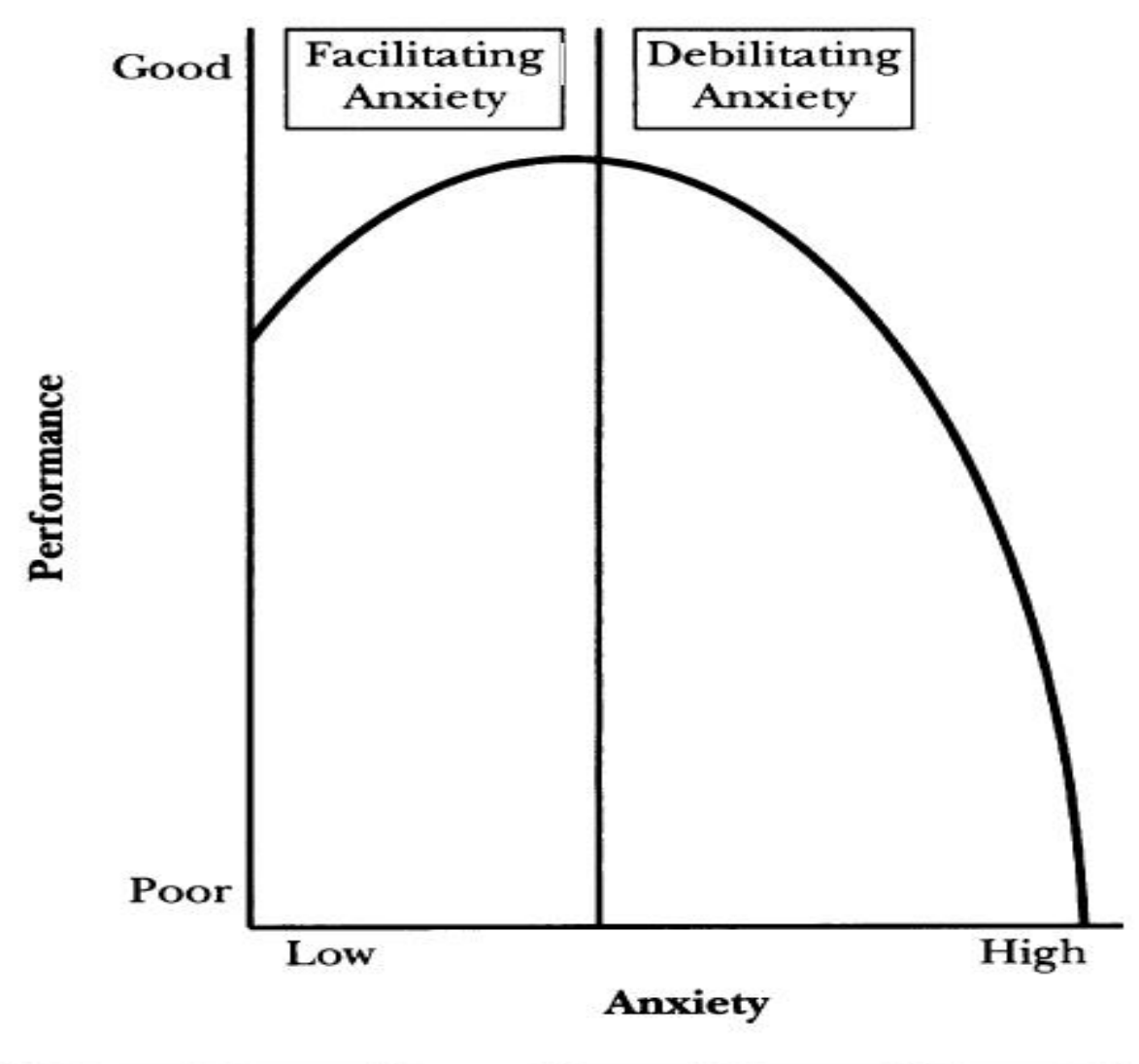

Figure 2. Inverted "U” Relations between Anxiety and Performance

\subsection{Intercultural Communication Apprehension}

Fear of interaction with people of different cultures is called intercultural communication apprehension (Neuliep and McCroskey, 1997). This can be explained through Uncertainty Reduction Theory which implies that in communication between two individuals who interact for the first time, uncertainty can arouse. More feeling of uncertainty leads to more anxiety (Kwok et al., 2001). Factors which can influence uncertainty level entail social identities, expectations, shared communicative networks, degree of similarities between interactants, and the interpersonal salience of the contact with stranger (Gudykunst \& Hammer, 1988). Intercultural communication apprehension can be decreased through responsiveness and assertiveness (McCroskey and Richmond, 1996). 


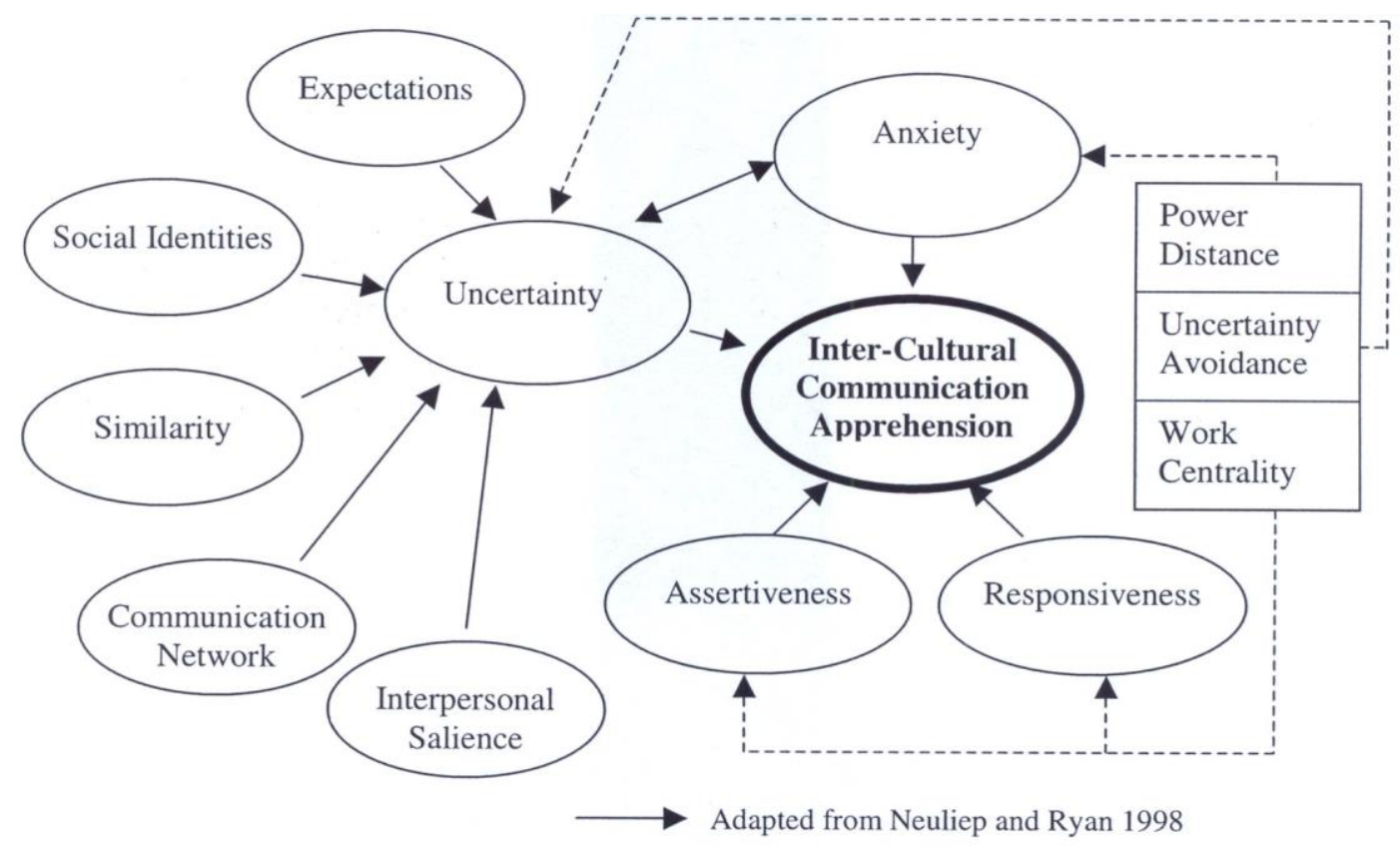

Figure 3. Potential Effects on Inter-Cultural Communication Apprehension

\section{Research Questions}

Given the significance of creating an anxiety-free environment for successful foreign language learning, the current study seeks to investigate the factors which provoke anxiety in language learners and strategies which can be adopted to help cope with those anxiety provoking factors. In this respect, the research questions to be addressed in the current study are:

What are the most anxiety provoking factors in foreign language speaking classrooms?

What are the most common strategies to cope with foreign language speaking anxiety?

\section{Methodology}

\subsection{Participants}

The participants of this study were ten first year undergraduate students of English education in Universiti Teknologi Malaysia. This university is located in the south part of Malaysia in Johor state. The rationale for selecting this university was that it was where the researcher was studying. Furthermore, it was one of the top ranked international universities in the world.

The participants were selected based on their availability. All of these participants had the same condition. They were all females, Malaysians, in their early twenties, and in the same class. Also, based on their marks in the first semester, they were at the same proficiency level. In addition, all the other students in their class were females which reduced the tension of presence of students of the opposite gender. 


\section{$\triangle$ Macrothink}

The rational for selecting participants of the same condition was to reduce the influence of demographic variables such as age, gender, grade, and cultural background on the results. The rationale for selecting students of the first year was that freshmen tend to experience more anxiety than their senior peers. Finally, the rationale for selecting students of English education was that they are considered to be more fluent and accurate English speakers.

\subsection{Instruments}

This research utilized a qualitative research methodology. The instruments used to collect the data were interview and reflective journal. A set of five questions were used to interview participants. These questions elicited language learners' ideas regarding the factors which made them anxious while speaking in the target language as well as strategies to reduce these factors (see appendix).

Participants were also asked to write two reflective journals following two speaking sessions. Reflective journals elicited participants' in-depth experience of anxiety immediately following each speaking session. These reflective journals were utilized to confirm the data derived from interviews.

The reason for using qualitative research method in the form of interview and reflective journal was that unlike quantitative research method based on questionnaires which elicit participants' attitudes toward some fixed predetermined ideas by the researcher, participants could express and elaborate their own ideas regarding anxiety.

\subsection{Procedure}

Participants of this study were chosen from among those students of the selected classroom who were willing to participate in interview and reflective journal writing. Before conducting interviews, permission was gained from participants to record the interviews. They were also ensured that the information obtained from interviews and reflective journals will be kept confidential and all the recordings will be deleted following data analysis.

Following the interviews, they were given two slips of papers with some instructions on what to include in them in order to write their reflections toward their anxious feelings immediately following each speaking session. The reason for emphasizing to write their reflective journals immediately after each speaking session was that they could easily convey their real feelings which they experienced in the class to the paper. However, if the time passed, they might not have the exact feelings and might not tend to write their exact feelings.

The participants were given a 7- to 10-day period to complete their reflective journals and return them to the researcher. The reason for giving them a 7- to 10-day period was that their speaking sessions were held only twice a week. These reflective journals also gave them the opportunity to feel relaxed writing the things they might not feel relaxed to say during interview.

\subsection{Data Analysis}

To analyze the data, a total of two variables were taken into consideration namely factors 
causing anxiety and strategies to cope with anxiety. Data were analyzed based on content analysis. Interviews were transcribed. The data derived from transcribing interviews and reflective journals were coded using identification of categories of themes that emerged from the analysis. The results were tabulated and presented through description.

The factors and strategies which were suggested only once and were not included in both interviews and reflective journals were excluded from the results. The reason was that factors and strategies suggested by only one person and only via interview or reflective journal can be an exception or a person's perception at a certain time. Therefore, they cannot be considered as general influencing factors or strategies.

\section{Results}

\subsection{Factors of Anxiety According to Data Derived from Interviews}

Table 1 summarizes participants' ideas regarding factors of anxiety in foreign language speaking classrooms which were suggested through interviews. In general, it can be seen that participants suggested three major categories of factors as influencing the level of anxiety in language learners during a foreign language speaking session. These categories include personal factors, teachers' factors, and classmates' factors. For each of these categories, some subcategories were suggested.

Table 1. Factors of Anxiety Suggested through Interviews

\begin{tabular}{|c|c|c|c|c|c|c|c|c|}
\hline \multirow[t]{2}{*}{ Participants } & \multicolumn{4}{|c|}{ Personal Factors } & \multicolumn{3}{|c|}{ Teachers' Factors } & \multirow{2}{*}{$\begin{array}{c}\text { Classmates' } \\
\text { Factors } \\
\begin{array}{c}\text { Not paying } \\
\text { attention }\end{array}\end{array}$} \\
\hline & $\begin{array}{c}\text { Fear of } \\
\text { making } \\
\text { mistakes }\end{array}$ & $\begin{array}{l}\text { Speaking } \\
\text { without } \\
\text { preparation }\end{array}$ & $\begin{array}{l}\text { Speaking } \\
\text { in front } \\
\text { of class }\end{array}$ & $\begin{array}{l}\text { Unfamiliarity } \\
\text { with topic }\end{array}$ & $\begin{array}{c}\text { Assessing } \\
\text { language } \\
\text { learners' } \\
\text { performance }\end{array}$ & $\begin{array}{l}\text { Having high } \\
\text { expectations }\end{array}$ & $\begin{array}{l}\text { Being } \\
\text { strict }\end{array}$ & \\
\hline 01 & & & $\sqrt{ }$ & & $\sqrt{ }$ & & & \\
\hline 02 & $\sqrt{ }$ & $\sqrt{ }$ & $\sqrt{ }$ & & $\sqrt{ }$ & $\sqrt{ }$ & & \\
\hline 03 & & $\sqrt{ }$ & & & $\sqrt{ }$ & & & \\
\hline 04 & $\sqrt{ }$ & & & & & & $\sqrt{ }$ & $\sqrt{ }$ \\
\hline 05 & $\sqrt{ }$ & $\sqrt{ }$ & & $\sqrt{ }$ & & & $\sqrt{ }$ & \\
\hline 06 & & & & $\sqrt{ }$ & $\sqrt{ }$ & & & $\sqrt{ }$ \\
\hline 07 & & & & & & $\sqrt{ }$ & & \\
\hline 08 & & & $\sqrt{ }$ & & $\sqrt{ }$ & $\sqrt{ }$ & & \\
\hline 09 & & & $\sqrt{ }$ & & & & $\sqrt{ }$ & \\
\hline 10 & $\sqrt{ }$ & $\sqrt{ }$ & & $\sqrt{ }$ & & & & \\
\hline Total & 4 & 4 & 4 & 3 & 5 & 3 & 3 & 2 \\
\hline
\end{tabular}

The most number of anxiety provoking factors were attributed to language learners' personality traits. These factors were suggested to be fear of making mistakes, speaking without preparation, speaking in front of class, and unfamiliarity with the topic. On the contrary, the fewest number of anxiety provoking factors were attributed to classmates' 
behaviors. They were suggested to have an influence on language learners' anxious feeling just by not paying attention to what the speaker says. The teacher's role in influencing language learners' anxiety was also suggested to be assessing language learners' performance, expecting high performance from language learners, and being strict.

Although the most number of anxiety provoking factors were attributed to personal factors (4 items), teachers were rated to be the highest anxiety provoking factors in language learners. Fifty percent of all participants agreed that considering some marks for their speaking performance made them anxious. The most significant reason suggested by these participants was that the dominant assessment criterion for university students in Malaysia is the marks they receive for their class activities. On the contrary, classmates were rated the lowest anxiety provoking factors in language learners. Only 20 percent of participants suggested they feel anxious while their classmates do not pay attention to what they say.

\subsection{Factors of Anxiety According to Data Derived from Reflective Journals}

Table 2 summarizes participants' ideas regarding factors of anxiety during two foreign language speaking classrooms which were suggested through reflective journals. In general, it can be seen that the same categories and subcategories of anxiety provoking factors which were suggested through interviews have been suggested. However, a different percentage was devoted to each item during the analysis of reflective journals which suggests different findings. A combination of some of teachers' and personal factors were mentioned to be the most anxiety provoking factors while a combination of some of classmates' and personal factors were mentioned to be the least anxiety provoking factors.

Table 2. Factors of Anxiety Suggested through Reflective Journals

\begin{tabular}{|c|c|c|c|c|c|c|c|c|}
\hline \multirow[t]{2}{*}{ Participants } & \multicolumn{4}{|c|}{ Personal Factors } & \multicolumn{3}{|c|}{ Teachers' Factors } & \multirow{2}{*}{$\begin{array}{c}\text { Classmates' } \\
\text { Factors } \\
\begin{array}{c}\text { Not paying } \\
\text { attention }\end{array}\end{array}$} \\
\hline & $\begin{array}{l}\text { Fear of } \\
\text { making } \\
\text { mistakes }\end{array}$ & $\begin{array}{c}\text { Speaking } \\
\text { without } \\
\text { preparation }\end{array}$ & $\begin{array}{l}\text { Speaking } \\
\text { in front } \\
\text { of class }\end{array}$ & $\begin{array}{l}\text { Unfamiliarity } \\
\text { with topic }\end{array}$ & $\begin{array}{c}\text { Assessing } \\
\text { language } \\
\text { learners' } \\
\text { performance }\end{array}$ & $\begin{array}{l}\text { Having high } \\
\text { expectations }\end{array}$ & $\begin{array}{l}\text { Being } \\
\text { strict }\end{array}$ & \\
\hline 01 & & & $\sqrt{ }$ & & & & & \\
\hline 02 & $\sqrt{ }$ & $\sqrt{ }$ & $\sqrt{ }$ & & $\sqrt{ }$ & & & \\
\hline 03 & & $\sqrt{ }$ & & & & & & \\
\hline 04 & & & & & & & & $\sqrt{ }$ \\
\hline 05 & $\sqrt{ }$ & $\sqrt{ }$ & & & & & & \\
\hline 06 & & & & $\sqrt{ }$ & $\sqrt{ }$ & & & \\
\hline 07 & & & & & & $\sqrt{ }$ & & \\
\hline 08 & & & $\sqrt{ }$ & & $\sqrt{ }$ & & & \\
\hline 09 & & & & & & & $\sqrt{ }$ & \\
\hline 10 & $\sqrt{ }$ & & & $\sqrt{ }$ & & & & \\
\hline Total & 3 & 3 & 3 & 2 & 3 & 1 & 1 & 1 \\
\hline
\end{tabular}


According to this table, the highest rated anxiety provoking factors during these two speaking sessions were suggested to be assessing their speaking performance, speaking without preparation, fear of making mistakes, and speaking in front of class. These factors were agreed by 30 percent of participants. In contrast, the lowest rated anxiety provoking factors were suggested to be their classmates' lack of attention to what they were saying, strict teacher, and teacher's high expectations from students. These factors were agreed by just 10 percent of the participants.

\subsection{Strategies to Cope with Anxiety According to Data Derived from Interviews}

Table 3 summarizes participants' ideas regarding strategies to cope with anxiety in foreign language speaking classrooms which were suggested through interviews. In general, it can be seen that participants suggested three major categories of strategies as influencing in reducing the level of anxiety in language learners during a foreign language speaking session. These categories include personal strategies, teachers' strategies, and classmates' strategies. For each of these categories some subcategories were suggested.

Table 3. Strategies to Cope with Anxiety Suggested through Interviews

\begin{tabular}{|c|c|c|c|c|c|c|c|c|}
\hline \multirow[t]{2}{*}{ Participants } & \multicolumn{3}{|c|}{ Personal Strategies } & \multicolumn{4}{|c|}{ Teachers' Strategies } & \multirow{2}{*}{$\begin{array}{r}\text { Classmates' } \\
\text { Strategies } \\
\text { Peer's } \\
\text { support }\end{array}$} \\
\hline & $\begin{array}{c}\text { Practicing } \\
\text { more }\end{array}$ & $\begin{array}{c}\text { Prior } \\
\text { preparation }\end{array}$ & $\begin{array}{c}\text { Using } \\
\text { English } \\
\text { in daily } \\
\text { life }\end{array}$ & $\begin{array}{c}\text { Encouraging } \\
\text { language } \\
\text { learners to } \\
\text { speak }\end{array}$ & $\begin{array}{l}\text { Creating a } \\
\text { fun } \\
\text { environment }\end{array}$ & $\begin{array}{l}\text { Conducting } \\
\text { group } \\
\text { discussions }\end{array}$ & $\begin{array}{c}\text { Giving } \\
\text { feedback }\end{array}$ & \\
\hline 01 & & & & $\sqrt{ }$ & $\sqrt{ }$ & & & \\
\hline 02 & $\sqrt{ }$ & $\sqrt{ }$ & $\sqrt{ }$ & & $\sqrt{ }$ & & $\sqrt{ }$ & \\
\hline 03 & $\sqrt{ }$ & & & $\sqrt{ }$ & & & $\sqrt{ }$ & $\sqrt{ }$ \\
\hline 04 & & & $\sqrt{ }$ & $\sqrt{ }$ & & & & \\
\hline 05 & & $\sqrt{ }$ & & & $\sqrt{ }$ & $\sqrt{ }$ & & \\
\hline 06 & $\sqrt{ }$ & $\sqrt{ }$ & & & & $\sqrt{ }$ & & $\sqrt{ }$ \\
\hline 07 & & & $\sqrt{ }$ & & $\sqrt{ }$ & $\sqrt{ }$ & & \\
\hline 08 & $\sqrt{ }$ & $\sqrt{ }$ & & & & & $\sqrt{ }$ & \\
\hline 09 & & & & & $\sqrt{ }$ & $\sqrt{ }$ & & \\
\hline 10 & & & & $\sqrt{ }$ & $\sqrt{ }$ & & & \\
\hline Total & 4 & 4 & 3 & 4 & 6 & 4 & 3 & 2 \\
\hline
\end{tabular}

The most number of strategies to cope with anxiety was attributed to the methods and techniques adopted by teachers (4 items). These strategies include encouraging language learners to speak, giving them feedback, conducting group discussions, and creating a fun environment in the classroom. On the contrary, the fewest number of strategies to cope with anxiety was attributed to classmates' behaviors. They were suggested to have an influence on reducing language learners' anxious feeling just by helping them. The roles of personal strategies in reducing language learners' level of anxiety were also suggested to be practicing more, using English in daily life, and prior preparation. 


\section{MlMacrothink}

Journal for the Study of English Linguistics

ISSN 2329-7034

2016, Vol. 4, No. 1

The highest rated strategies suggested through interviews refer to the role of teachers. Sixty percent of participants suggested that creating a fun environment in foreign language speaking classroom can reduce anxiety. The most significant rationale suggested by participants was that they had enough knowledge to speak but they felt shy and they needed a funny environment to mask their reticence and cope with their anxiety. On the contrary, the lowest rated strategies suggested through interviews refer to the role of classmates. Only 20 percent of participants suggested that support from their classmates could reduce their anxiety level.

\subsection{Strategies to Cope with Anxiety According to Data Derived from Reflective Journals}

Table 4 summarizes participants' ideas regarding strategies to cope with anxiety during two foreign language speaking classrooms which were suggested through reflective journals. In general, it can be seen that the same categories and subcategories of strategies to cope with anxiety which were suggested through interviews have been suggested. However, a different percentage was devoted to each item during the analysis of reflective journals which does not violate the findings from interviews. Similar to the findings from interviews, creating a fun environment was suggested to be the most influential in reducing anxiety while support from peers was suggested to be the least influential one.

Table 4. Strategies to Cope with Anxiety Suggested through Reflective Journals

\begin{tabular}{|c|c|c|c|c|c|c|c|c|}
\hline \multirow[t]{2}{*}{ Participants } & \multicolumn{4}{|c|}{ Personal Strategies } & \multicolumn{3}{|c|}{ Teachers' Strategies } & $\begin{array}{r}\text { Classmates } \\
\text { Strategies }\end{array}$ \\
\hline & $\begin{array}{c}\text { Practicing } \\
\text { more }\end{array}$ & $\begin{array}{c}\text { Prior } \\
\text { preparation }\end{array}$ & $\begin{array}{c}\text { Using } \\
\text { English } \\
\text { in daily } \\
\text { life }\end{array}$ & $\begin{array}{c}\text { Encouraging } \\
\text { language } \\
\text { learners to } \\
\text { speak }\end{array}$ & $\begin{array}{l}\text { Creating a } \\
\text { fun } \\
\text { environment }\end{array}$ & $\begin{array}{l}\text { Conducting } \\
\text { group } \\
\text { discussions }\end{array}$ & $\begin{array}{c}\text { Giving } \\
\text { feedback }\end{array}$ & $\begin{array}{l}\text { Peer's } \\
\text { support }\end{array}$ \\
\hline 01 & & & & & $\sqrt{ }$ & & & \\
\hline 02 & $\sqrt{ }$ & $\sqrt{ }$ & & & $\sqrt{ }$ & & $\sqrt{ }$ & \\
\hline 03 & & & & & & & $\sqrt{ }$ & $\sqrt{ }$ \\
\hline 04 & & & & $\sqrt{ }$ & & & & \\
\hline 05 & & $\sqrt{ }$ & & & $\sqrt{ }$ & & & \\
\hline 06 & $\sqrt{ }$ & & & & & $\sqrt{ }$ & & \\
\hline 07 & & & $\sqrt{ }$ & & & $\sqrt{ }$ & & \\
\hline 08 & $\sqrt{ }$ & $\sqrt{ }$ & & & & & & \\
\hline 09 & & & & & $\sqrt{ }$ & $\sqrt{ }$ & & \\
\hline 10 & & & & $\sqrt{ }$ & & & & \\
\hline Total & 3 & 3 & 1 & 2 & 4 & 3 & 2 & 1 \\
\hline
\end{tabular}

According to this table, the highest rated strategy to cope with anxiety during these two speaking sessions was suggested to be creating a fun environment in the foreign language speaking classroom. This strategy was agreed by 40 percent of participants. In contrast, the lowest rated strategy to cope with anxiety was suggested to be support from their peers. This strategy was agreed by just 10 percent of the participants. The most significant reason which 
they mentioned for this low percentage of strategies attributed to classmates was that there already existed a friendly relationship among language learners in this class and they did not expect a further support from their peers.

\section{Discussion}

A comparison between results derived from interviews and those of reflective journals suggests that the same factors and strategies which were suggested by language learners during interviews were mentioned in their reflective journals as well. However, not every factor introduced in the interviews was suggested in the reflections. The reason might be they did not experience particular types of anxiety or did not find some particular types of strategies suitable during those two speaking sessions. This implies that every language learner's perception of anxiety is different from the others and there is a certain number of factors and strategies which can provoke or reduce anxiety in an individual, but not all these factors and strategies might be experienced or applicable at a specific time.

As can be seen in tables 1,2,3, and 4, the findings from reflective journals fully support the findings from interviews. According to interviews, the highest rated anxiety provoking factor was suggested to be assessing language learners' speaking performance. This factor is among the highest rated ones in reflective journals. Also, the highest rated strategy to cope with anxiety was suggested to be creating a fun environment in the classroom. This strategy is rated the highest in reflective journals as well. A look at the opposite side shows that according to interviews the lowest rated anxiety provoking factor was suggested to be classmates' lack of attention to language learners' speaking. This factor is also among the lowest rated ones in reflective journals. Also, the lowest rated strategy to cope with anxiety was suggested to be support from classmates. This factor is also among the lowest rated ones in reflective journals.

What is interesting in findings from both interviews and reflective journals is that although all participants agreed on feeling anxious while speaking English in foreign language classrooms, very few factors and strategies were suggested by most of them. This implies that although the researcher tried to reduce the probability of anxiety in language learners by reducing the influence of demographic variables and selecting students of English education, there still existed some factors which made them anxious and more or less all participants felt anxious during speaking sessions for some reasons. Also the highest ranked factors and strategies to cope with speaking anxiety in a foreign language classroom are attributed to the role of teachers. The reason can be attributed to the fact that classes are still teacher-centered and it is the teacher who controls every aspect of classroom, even language learners' participation in class interactions. This fact is in contrary with the attempts of language practitioners and course book designers toward a student-centered language learning environment based on the modern language teaching methods such as communicative language teaching method.

In general, compared to most other studies which utilized Horwitz's Likert Scale questionnaire, the findings of this research can be more reliable. The reason is that this questionnaire elicited language learners' ideas toward a set of fixed factors which can generally cause anxiety in language learners and strategies to cope with them and did not let 
language learners to express their real feelings of anxiety. However, since the participants in this study came from the same background (gender, nationality, age, educational level, and major), the type of suggested factors and strategies centered on the perception of language learners of the same characteristics. This implies that including participants with a greater range of demographic variables could add more factors of anxiety to this study.

\section{Conclusion}

The most significant finding which has been emerged from this study is the role of teachers in creating and/or controlling anxiety. According to the findings of this study, teachers play the most significant role in creating anxiety in language learners during a foreign language speaking session. At the same time, they were also suggested to be the ones who could help more in reducing language learners' tension and anxiety during a speaking session by adopting various techniques and methods. In this regard, the most anxiety provoking factor was suggested to be teacher's assessment of language learners' performance. The most frequent strategy used to cope with anxiety was also suggested to be creating a fun environment in the class by teachers.

\section{Acknowledgement}

Earnest gratitude goes to Ahmad Rafieyan who inspired the author with the research idea.

\section{Appendix}

Interview questions

1. What makes you anxious while speaking English in the classroom?

2. What kinds of situations cause stress or anxiety for you in language classroom?

3. How does your language teacher play a role in creating or reducing anxiety in students?

4. What can be useful to make you speak voluntarily in language classroom?

5. What do you suggest in order to reduce language anxiety in students?

\section{References}

Atay, D., \& Kurt, G. (2006). Prospective teachers and L2 writing anxiety. Asian EFL Journal, 8(4). Retrieved on March 15, 2008 from http://www.asian-efljournal.com/Dec_06_ du\&gk.php

Bailey, K. M. (1983). Competitiveness and anxiety in adult second language learning: looking at and through the dairy studies. In H. W. Seliger, \& M. H. Long (Eds.), Classroom Oriented Research in Second Language Acquisition (pp. 67-103). Rowley, MA: Newbury House Publishers Inc.

Elkhafaifi, H. (2005). Listening comprehension and anxiety in the Arabic language classroom. $\begin{array}{lllll}\text { The } & \text { Modern } & \text { Language } & \text { Journal, } 220 .\end{array}$ http://dx.doi.org/10.1111/j.1540-4781.2005.00275.x

Ellis, R. (1994). The Study of Second Language Acquisition. Oxford, UK: Oxford University 
Press.

Eysenck, M. W. (1979). Anxiety, learning, and memory: A reconceptualization. Journal of Research in Personality, 13(4), 363-385. http://dx.doi.org/10.1016/0092-6566(79)90001-1

Gudykunst, W. B., \& Hammer, M. R. (1988). "Strangers and hosts: An uncertainty reduction based theory of intercultural adaption" in: Y. Kim, \& W. B. Gudykunst (Eds.), Cross-cultural adaption (pp. 106-139), Newbury Park: Sage.

Hembree, R. (1988). Correlates, causes, effects, and treatment of test anxiety. Review of Educational Research, 58, 47-77. http://dx.doi.org/10.3102/00346543058001047

Horwitz, E. K. (1991). Preliminary evidence for the reliability and validity of a foreign language anxiety scale. In E. K. Horwitz and D. J. Young (Eds.). Language anxiety: From theory and research to classroom implications (pp. 37-39). Englewood Cliffs, NJ: Prentice Hall.

Horwitz, E. K., Horwitz, M. B., \& Cope, J. (1986). Foreign language classroom anxiety. The Modern Language Journal, $\quad 70, \quad 125-132$. http://dx.doi.org/10.1111/j.1540-4781.1986.tb05256.x

Kondo, D. S. (1997). 'Strategies for coping with test anxiety'. Anxiety, Stress, and Coping, 10, 203-15. http://dx.doi.org/10.1080/10615809708249301

Krashen, D. (1980). The input hypothesis. In J. E. Alatis (Ed.), Current issues in bilingual education: Georgetown University Round Table on Language and Linguistics (pp. 168-180). Washington, DC: Georgetown University Press.

Kwok, R. C., Lee, M., \& Turban, E. (2001) 'On Inter-organizational EC Collaboration: The Impact of Intercultural Communication Apprehension', Proceedings of the $34^{\text {th }}$ Hawaii International Conference on System Sciences (2001), 2001, IEEE. http://dx.doi.org/10.1109/HICSS.2001.926191

MacIntyre, P. D. (1995). How does anxiety affect second language learning? A reply to Sparks and Ganschow. The Modern Language Journal, 79, 90-99. http://dx.doi.org/10.1111/j.1540-4781.1995.tb05418.x

MacIntyre, P. D., \& Gardner, R. C. (1991a). Investigating language class anxiety using the focused essay technique. The Modern Language Journal, 75, 296-304. http://dx.doi.org/10.1111/j.1540-4781.1991.tb05358.x

MacIntyre, P. D., \& Gardner, R. C. (1991b). Language anxiety: Its relation to other anxieties and to processing in native and second languages. Language Learning, 41, 513-534. http://dx.doi.org/10.1111/j.1467-1770.1991.tb00691.x

McCroskey, J. C., \& Richmond, V. P. (1996). Fundamentals of human communication: An interpersonal perspective. Prospect Heights, IL: Waveland Press.

Neuliep, J. W., \& McCroskey, M. C. (1997) 'The Development of Intercultural and Interethnic Communication Apprehension Scales'. Communication Research Reports, 14 (2), 145-156. http://dx.doi.org/10.1080/08824099709388656

Phillips, G. M. (1991). Communication incompetencies: A theory of training oral performance behavior. Carbondale: Southern Illinois University Press.

Phillips, E. M. (1992). The effects of language anxiety on students' oral test performance and 
attitudes.

Modern

Language 2016, Vol. 4, No. 1

http://dx.doi.org/10.1111/j.1540-4781.1992.tb02573.x

Journal

76 ,

$14-26$.

Price, M. L. (1991). The subjective experience of foreign language anxiety: Interviews with highly anxious students. In E. K. Horwitz \& D. J. Young (Eds.), Language anxiety: From theory and research to classroom implications (pp. 101-108). Englewood Cliffs, NJ: Prentice-Hall.

Scovel, T. (1978). The effect of affect on foreign language learning: A review of the anxiety research. Language Learning, 28(1), 129-142. http://dx.doi.org/10.1111/j.1467-1770.1978.tb00309.x

Sellers, V. (2000). Anxiety and reading comprehension in Spanish as a foreign language. Foreign Language Annals, 33, 512-521. http://dx.doi.org/10.1111/j.1944-9720.2000.tb01995.x

Sparks, R. L., \& Ganschow, L. (1991). Foreign language learning differences: Affective or native language aptitude differences? The Modern Language Journal, 75, 3-16. http://dx.doi.org/10.1111/j.1540-4781.1991.tb01076.x

Spielberger, C. D. (1983). Manual for the state-trait anxiety inventory (Form Y). Palo Alto: Consulting Psychological Press.

Tobias, S. (1985). Test Anxiety: Interference, Defective Skills, and Cognitive Capacity. Educational Psychologist, 20, 135-142. http://dx.doi.org/10.1207/s15326985ep2003_3

Yamashiro, A., \& McLaughlin, J. (2001). Relationships among attitudes, motivation, anxiety, and English language proficiency in Japanese college students. In: JALT Applied Materials: Second Language Research in Japan (pp. 113-127). Tokyo, Japan: JALT.

Young, D. J. (1990). An investigation of students' perspectives on anxiety and speaking. Foreign Language Annals, 23, 539-553. http://dx.doi.org/10.1111/j.1944-9720.1990.tb00424.x

Young, D. J. (1991). Creating a low-anxiety classroom environment: What does language anxiety research suggest? The Modern Language Journal, 75, 426-439. http://dx.doi.org/10.1111/j.1540-4781.1991.tb05378.x

\section{Copyright Disclaimer}

Copyright for this article is retained by the author(s), with first publication rights granted to the journal.

This is an open-access article distributed under the terms and conditions of the Creative Commons Attribution license (http://creativecommons.org/licenses/by/3.0/). 